\title{
HET ZEVENDE INTERNATIONAAL ACCOUNTANTSCONGRES 1957
}

\author{
door Dr. A. Th. de Lange
}

De Redaktie van het Maandblad voor Accountancy en Bedrijfshuis houdkunde heeft besloten ter gelegenheid van het Zevende Internationaal Accountantscongres, dat van 9-13 september 1957 in het Concertgebouw te Amsterdam is gehouden, een speciaal Congresnummer te doen verschijnen. In dit nummer vindt de lezer nabeschouwingen over de onderscheiden onderwerpen, welke op het Congres aan de orde zijn gesteld. Ter inleiding van deze verhandelingen gaan enkele beschouwingen over doelstelling en werkwijze der samenkomsten vooraf.

Het Accountantscongres 1957 heeft ongeveer 1600 accountants uit 40 landen bijeengebracht, teneinde over hun gemeenschappelijke vakproble men van gedachten te wisselen. De vaststelling van het gemeenschappelijke in de vraagstukken, welke zich in de vertegenwoordigde landen op het gebied der accountancy voordoen, is echter meestal geen eenvoudige zaak. De omstandigheden, waaronder het beroep in alle delen der wereld wordt uitgeoefend, de graad van ontwikkeling van het beroep en de betekenis, welke mede dientengevolge aan de accountantsverklaringen in de betrokken gemeenschappen wordt gehecht, lopen zozeer uiteen, dat de vraagstukken, welke voor de beroepsgenoten in de onderscheiden landen van wezenlijke betekenis zijn, eveneens van zeer verschillende aard zijn. Hierin schuilt een fundamentele moeilijkheid, welke zich bij de organisatie van vele internationale samenkomsten doet gelden en welke reeds bij de vaststelling van de te behandelen onderwerpen naar voren komt.

Zowel de referaten als de paneldiscussies dragen, zoals in de hiernavolgende verhandelingen telkenmale naar voren komt, duidelijk de sporen van deze uiteenlopende belangstelling voor de onderscheidene facetten van elk vraagstuk. Dat het Congrescomite er niettemin in geslaagd is niet alleen de onderwerpen te vinden, waarvoor bij een groot aantal deelnemers aan het Congres belangstelling kan worden gewekt, maar ook een methode van behandeling der problemen te ontwerpen, welke een vruchtbare gedachtenwisseling heeft mogelijk gemaakt, stemt dan ook tot grote voldoening.

Het zou onverstandig zijn de verwachting te wekken, dat de beraadslagingen in de panels tot conclusies zouden kunnen leiden, welke zonder meer voor toepassing in de beroepsuitoefening in de betrokken landen vatbaar zijn. Maar wel kan ernaar worden gestreefd, dat de discussies nieuwe gezichtspunten voor de congressisten openen, welke bij de behandeling van het vraagstuk in het eigen land niet naar voren zijn gekomen. De betekenis van een internationale gedachtenwisseling moet in het bijzonder gezocht worden in het verbreken van de banden, welke een nationale discussie plegen te omsluiten. Het beluisteren van een geheel andere denkwijze en het waarnemen van geheel andere facetten van het vraagstuk dan waarmede men in het eigen land vertrouwd is, kan de kennis en het inzicht van hem, die bereid is te luisteren en waar te nemen, verruimen.

De discussies in de panels zijn zeer bevorderd door de intense voorbereidingen vanwege het Congrescomité. Reeds geruime tijd voor de samenkomst der Congressisten zijn de inleidingen - in de regel 5 in getal per onderwerp - en de door de rapporteurs opgestelde samenvattingen aan de panelleden toegezonden en voorgelegd aan voor ieder onderwerp inge -

m a b blz. 366 
stelde sub-commissies voor de werkzittingen, waarin om redenen van doelmatigheid alleen Nederlandse accountants zitting hadden. Deze commissies hebben de paneldiscussies in belangrijke mate beheerst door de formulering van de vragen, waarover naar aanleiding van referaten en samenvatting van de rapporteur van gedachten zou kunnen worden gewisseld en welke van voldoende internationale betekenis zouden zijn om de belangstelling van panelleden en congressisten te wekken. Kort voor de werkzittingen hebben de panels, waarin zoveel mogelijk landen waren vertegenwoordigd, hun keuze uit deze vragen gedaan. Uliteraard is niet in alle panels de doelstelling tot een levendige, vele panelleden activerende gedachtenwisseling te geraken, even goed bereikt. Niettemin mag worden gesteld, dat de voorbereidingen geenszins tevergeefs zijn geweest en dat een ordelijke discussie zeer is bevorderd. Wellicht moge voor volgende congressen ter harte worden genomen, dat men veel gemakkelijker tot een overdaad van vragen kan geraken dan tot een duidelijke uiteenzetting van de standpunten omtrent de wezenlijke verschillen van opvatting.

Over enige tijd zal het Congresboek, waarin men de inleidingen, samenvattingen en discussies volledig zal aantreffen, verschijnen. Een herinnering aan de festiviteiten van het Congres zal evenmin ontbreken. De Redaktie meent haar lezers evenwel een dienst te bewijzen reeds nu een samenvatting van de prestaties op het terrein der beroepsuitoefening te geven. 